\title{
Biological Denitrification of Groundwater Using a Fluidized Bed Reactor
}

\author{
JOSEPH D. ROUSE ${ }^{1}$, YIMIN ZHU ${ }^{2}$, KENJI FURUKAWA ${ }^{1}$, and KENJI KIDA ${ }^{2}$ \\ ${ }^{1}$ Department of Civil Engineering and Architecture, \\ ${ }^{2}$ Department of Applied Chemistry and Biochemistry, \\ Faculty of Engineering, Kumamoto University, Kurokami 2-39-1, \\ Kumamoto 860-0862, Japan
}

\begin{abstract}
Biological denitrification using sponge carriers for retention of biomass in a fluidized bed reactor with gas recirculation was investigated. Using ethanol as a carbon source, nitrate contaminated groundwater (20 $\mathrm{mg} / l$ as nitrogen) was treated at various hydraulic retention times (HRT) and carbon to nitrogen ratios $(C: N)$ to assess system capabilities. Near complete removal of influent nitrate was achieved with a $\mathrm{C}: \mathrm{N}$ of 1.9 or greater at a HRT of 1.25 hours. A gradual reduction in $\mathrm{C}: \mathrm{N}$ from 1.9 to 1.0 resulted in a concurrent reduction in nitrogen removal efficiency to about $65 \%$. However, removal efficiencies of total organic carbon (TOC) were improved from about $75 \%$ (at $\mathrm{C}: \mathrm{N}$ of 1.9 ) to $95 \%$ (at $\mathrm{C}: \mathrm{N}$ of 1.0) with effluent TOC concentrations falling below $2.0 \mathrm{mg} / l$. The benefits of operation with reduced TOC and solids output at the expense of nitrogen removal efficiency was discussed. The sponge biocarriers demonstrated favorable potential for retention of essential biomass in a denitrification unit process.
\end{abstract}

Key words : groundwater, nitrate pollution, denitrification, fluidized bed reactor, biomass retention

\section{INTRODUCTION}

In Japan, groundwater sources account for about $1 / 7$ of the total water supply and $1 / 3$ of the municipal demand with some 30 million people using groundwater as a potable water resource.) Groundwater is an attractive option versus surface water due to its comparatively high quality, less seasonal temperature variation, and low volume fluctuations. However, groundwater quality surveys conducted by the Environmental Agency have revealed an increasing trend in the detection of pollutants such as aliphatic chlorinated hydrocarbons (e.g., trichloroethylene) and other petroleum based contaminants. Nitrate contamination is also reported to be increasing in groundwater reservoirs with concentrations approaching and sometimes exceeding the drinking water quality standard of $10 \mathrm{mg} / l$ as nitrogen.

Concurrent with agricultural development in Kumamoto Prefecture (e.g., production of water melons in Ueki Town, sweet oranges in Kawachi Town, and peaches in Arai City), large amounts of nitrogen containing fertilizers have been applied to land surfaces. High nitrogen-bearing animal waste in farming regions is also frequently disposed of without adequate treatment, thus further 
endangering groundwater quality. Accelerated eutrophication has occurred in Lake Ezu (in Kumamoto City) due to biostimulation caused, in part, by high nitrate levels in the groundwater feeding this water body. Furthermore, nitrate in drinking water in excess of the regulatory standard can lead to methemoglobinemia (blue baby syndrome) in infants after transformation to nitrite in their digestion track. It is also reported that nitrate in drinking water may increase the risk of gastric cancer after reduction to nitrite in saliva and reaction with amines resulting in formation of carcinogenic nitrosamines. $^{2,3)}$

The need for treatment methods to remediate nitrate contaminated groundwater is evident. Nitrogen abatement processes can be either physical/chemical or biological in nature. The prior category (including ion exchange, reverse osmosis, and electrodialysis) offers the advantages of process control, simplicity of operation, and capacity to be automated. The main disadvantage is that nitrate is only separated from the waste stream to another phase which then must be disposed of or reprocessed at additional expense. Conversely, biological treatment has the advantage of converting soluble oxidized forms of nitrogen (nitrate and nitrite ions) to gaseous forms. Efficient biological denitrification processes ultimately result in transformation to dinitrogen gas, the only environmentally safe form of nitrogen.

Denitrifying bacteria are facultative organisms that utilize oxidized forms of nitrogen as electron acceptors in the absence of molecular oxygen. Most are heterotrophs, using organic compounds as a source for assimilatory carbon. Retention of essential microbial species is an important factor in effectuating an efficient high rate anoxic denitrification unit process, thus some form of biomass carrier or sludge granulation is advantageous. ${ }^{4}$, 5) The objective of this study was to evaluate the use of a sponge material to support growth of heterotrophic denitrifying organisms in a groundwater treatment process. This was met by conducting continuous bench-scale denitrification assays in a fluidized bed reactor (FBR) with the unique support matrix under various testing conditions (i.e., variation of chemical additions and application rates) and evaluation of system performance (e.g., biomass retention and nitrate and organic carbon attenuation).

\section{MATERIALS AND METHODS}

Groundwater Potable tap water amended with $\mathrm{NaNO}_{3}$ was used as influent for all assays. Tap water in Kumamoto City is solely of groundwater origins with a $\mathrm{pH}$ of 6.9 and, as prepared for this study, consisted of: $\mathrm{NO}_{3}-\mathrm{N}, 20 \mathrm{mg} / \mathrm{l} ; \mathrm{NO}_{2}-\mathrm{N}$, below detection; $\mathrm{Ca}^{2+}, 18 \mathrm{mg} / l ; \mathrm{Mg}^{2+}, 7.3 \mathrm{mg} / l ; \mathrm{SO}_{4}{ }^{2-}$, $37 \mathrm{mg} / l$; and $\mathrm{PO}_{4}{ }^{3-}, 0.24 \mathrm{mg} / l$.

Seed Sludge and Biomass Support Material The seed sludge used for the FBR was obtained from an activated sludge process of the Northern Wastewater Treatment Plant of Kumamoto Prefecture. Its MLSS and VSS concentrations were $1100 \mathrm{mg} / l$ and $970 \mathrm{mg} / l$, respectively. The activated sludge liquor had a pH of 7.5 and contained: total organic carbon (TOC), $6.8 \mathrm{mg} / l$; inorganic carbon (IC), $37 \mathrm{mg} / l$; volatile fatty acids (VFA), non-detect; $\mathrm{NH}_{4}-\mathrm{N}$, $20 \mathrm{mg} / l$; and $\mathrm{NO}_{3}-\mathrm{N}, 1.0 \mathrm{mg} / l$. Two liters of this activated sludge seed was used as the initial reactor inoculum. The sponge biomass support medium consisted of $5 \mathrm{X} 5 \mathrm{~mm}$ cubes with $100 \mu \mathrm{m}$ pore size (Bz-H05T(100), Biomaterial Co., Ltd., Japan) and was used at a $1.0 \% \mathrm{w} / \mathrm{v}$ addition (i.e., 10 g-dry weight $/ l$ ).

Continuous Flow Denitrification Assays A schematic of the FBR used for continuous 
flow denitrification assays is shown in Figure 1. The reactor was made of Pyrex glass and had a height of $650 \mathrm{~mm}$ with an inner diameter of $70 \mathrm{~mm}$. The effluent port was $480 \mathrm{~mm}$ from the base, setting the working volume at $2.0 \mathrm{l}$. The draft tube, with an inner diameter of $28 \mathrm{~mm}$, was positioned to enhance circulation of the sponge biomass support cubes. Fluidization and circulation of the media was achieved by recirculation of nitrogen gas in conjunction with the upflow of influent groundwater (not recycled).

The nitrate bearing groundwater and a $20 \%$ ethanol solution were pumped to the reactor from two separate influent tanks. Hydraulic retention time (HRT) and nitrogenous volumetric loading rate (VLR) were controlled by adjustments in influent flow rates. Carbon to nitrogen ratio $(\mathrm{C}: \mathrm{N})$ was altered by adjustments to the influent ethanol flow rate. The groundwater used for

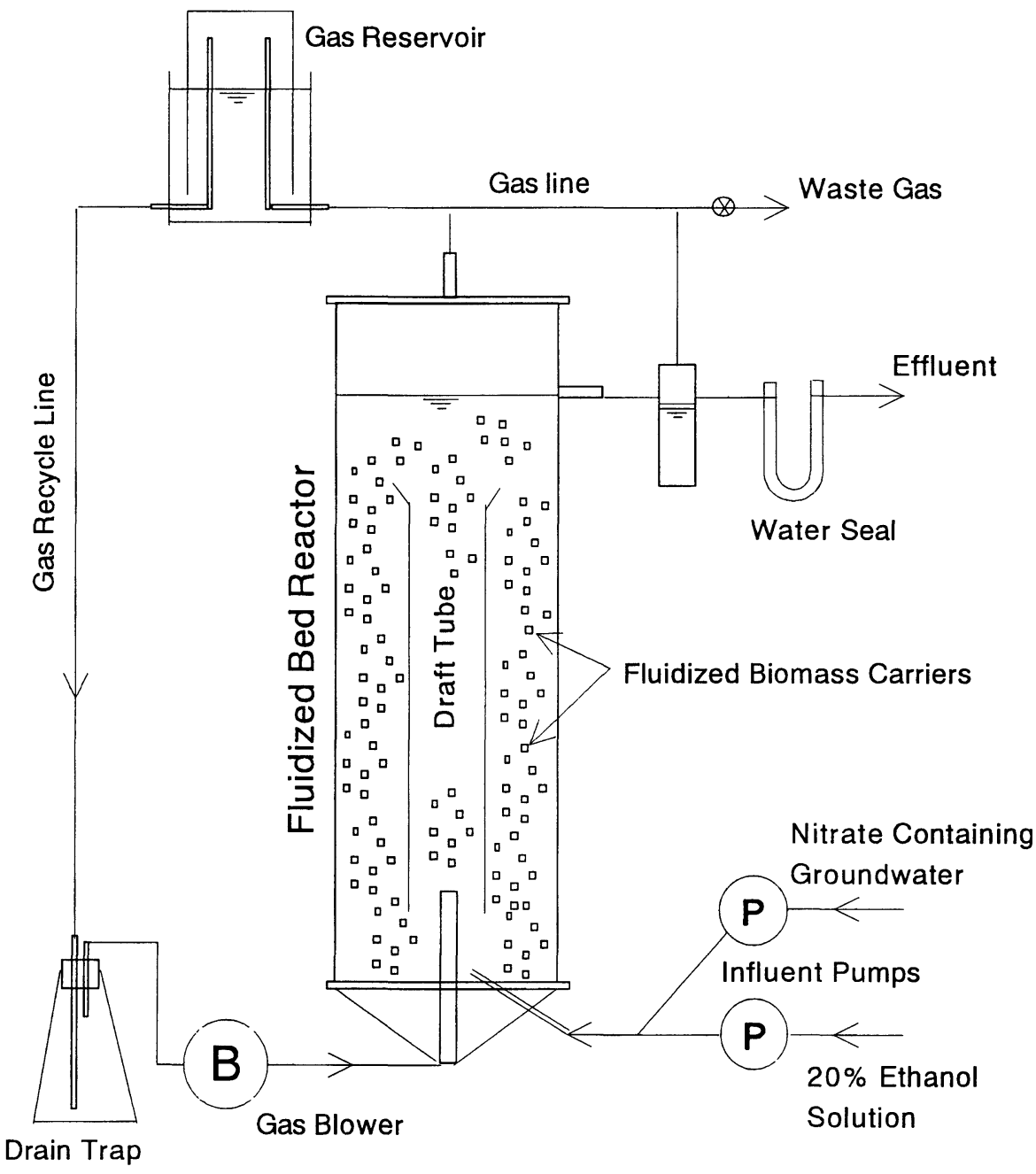

Fig. 1 Schematic diagram of fluidized bed reactor (FBR) used for denitrification assays. See text (Materials and Methods) for dimensions. 
influent mixtures was not stripped of dissolved oxygen before use. The reactor was operated at $30^{\circ} \mathrm{C}$, maintained thermostatically with an external ribbon heating element.

Scanning Electron Microscopy (SEM) Preparation of the sponge support material for electron microscopy consisted of dewatering in ethanol at concentrations of 10 $\%, 50 \%, 70 \%, 90 \%$, and $95 \%$ for 10 minutes at each concentration and then holding the sample in $100 \%$ t-butyl alcohol overnight. Critical point drying was conducted on a Nihondenshi Co., Ltd., JFD-300 Critical Point Dryer. Gold coating was done with an ion sputtering device (JFL-1100E, Nihondenshi Co., Ltd.). Cleavage of sponge cubes was done after critical point drying using a sharp cutter knife. SEM observations were made on a Nihondenshi JSM-531LV.

Analytical Methods Prior to analysis, water samples were centrifuged at $10,600 \mathrm{~g}$ for 10 minutes and filtered through a 0.45 $\mu \mathrm{m}$ membrane filter. Filtrate was used for the measurement of TOC, VFA, and ionic components. TOC was determined on a TOC analyzer (Model 500, Shimazu, Japan). VFA levels were determined by the post label method using a high pressure liquid chromatograph (Model 860C, Nihonbunkoh, Japan) with an organic acid analytical column (Shimpack SCR-101H, Shimazu) followed with color development after separation with BTB reagent. All ionic components were determined by ion chromatography (DX-AQ, Nihon-Dionex, Japan). IonPac's CG12 and CS12 were used for separation of anions and IonPac's AG12A and AS12A were used for separation of cations.

\section{RESULTS}

System Start-up and Operation Initially, sponge carriers tended to clog in the lower conical section of the reactor and between the side wall and draft tube. A gas circulation rate of $3.0 \mathrm{l} / \mathrm{min}$ was found to be necessary to maintain fluidization and circulation of the sponge carriers. Initial gas production, however, was too low to achieve fluidization due to the low nitrate application rate $(\mathrm{VLR}=0.019 \mathrm{~g}-\mathrm{N} / l / \mathrm{d})$ used while developing biomass. The gas reservoir was thus stocked with $4.0 \mathrm{l}$ of nitrogen gas which sufficed to maintain circulation in the reactor and positive pressure in the gas lines, insuring anoxic conditions during reactor start-up. Subsequently, with maturation of biomass, a nitrogenous VLR in excess of $0.64 \mathrm{~g}-\mathrm{N} / \mathrm{l} / \mathrm{d}$ (HRT less than $0.75 \mathrm{hr}$ ) was shown to be sufficient to evolve the necessary gas for continuous, positive pressure operation.

HRT was kept at $25 \mathrm{hr}$ during system start-up and was reduced to $4.0 \mathrm{hr}$ after 10 days. Adequate biomass had developed during this time to achieve nearly complete nitrogen removal. With the intention of supplying carbon at a non-limiting level (see following discussion), influent $\mathrm{C}: \mathrm{N}$ was maintained at 1.9 or greater during the first 130 days of operation when variations in HRT were assessed. Due to difficulties encountered in operating the influent ethanol pump at low flow rates, considerable variation in $\mathrm{C}: \mathrm{N}$ occured during this initial period (average $\mathrm{C}: \mathrm{N}=3.1$, standard deviation $(\mathrm{SD})=0.8)$. Subsequent improvement in techniques allowed for greater accuracy with this parameter during the concluding assays (following day 130) where effects of variations in $\mathrm{C}: \mathrm{N}$ on system performance were assessed (see following discussion).

Continuous Treatment Experiments A chronology of system results demonstrating performance over about six months of operation under various testing conditions is shown in Figure 2. Following system start-up (days 1 to 10 ), nearly complete removal of 
Efflu. TOC \& $\mathrm{NO}_{3}-\mathrm{N}(\mathrm{mg} / \mathrm{l})$,

Nitrogen Removal (\%)

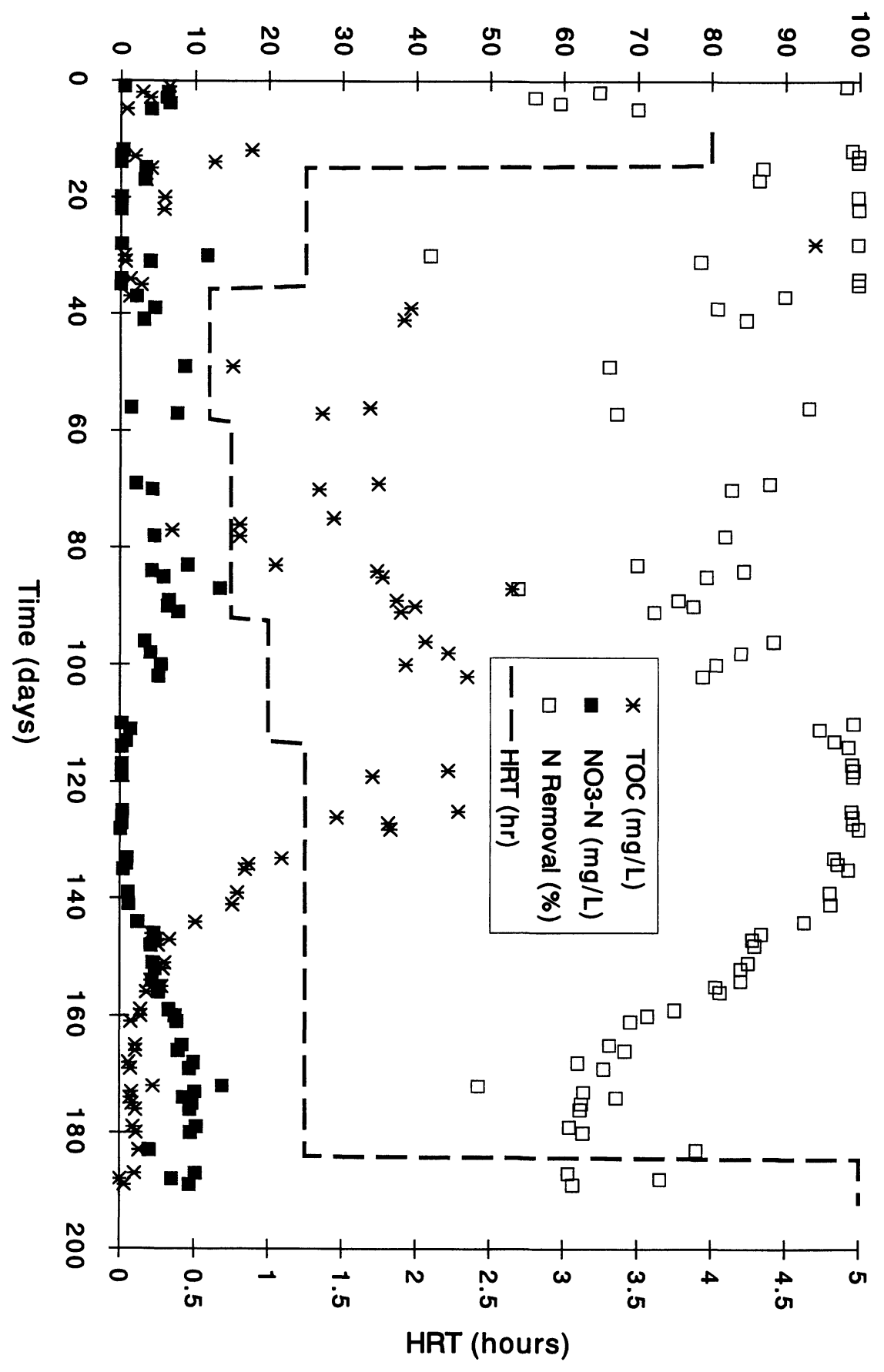

Fig. 2 Time course of fluidized bed reactor (FBR) performance as a function of hydraulic retention time (HRT). Influent $\mathrm{C}: \mathrm{N}$ was 1.9 or greater for HRT variation assays through day 130 then reduced from about 2.3 to 1.0 between days 130 and 160 and maintained at 1.0 though day 190 (see text). 
nitrogen at a HRT of $4.0 \mathrm{hr}$ was achieved. HRT was then reduced stepwise to $1.25 \mathrm{hr}$ and $0.60 \mathrm{hr}$ with resulting nitrogen removal efficiencies of about $100 \%$ and $60 \%$, respectively. Subsequently, HRT was increased stepwise and a HRT of $1.25 \mathrm{hr}$ was confirmed to be necessary to maintain near complete removal of applied nitrogen with an influent $\mathrm{C}: \mathrm{N}$ of 1.9 or greater. Nitrite ion was detected in the effluent at HRTs less than 1.25 hours (data not shown) but not at higher HRTs.

Prior to day 30, at HRTs of $4.0 \mathrm{hr}$ and $1.25 \mathrm{hr}$, effluent TOC averaged about 5.0 $\mathrm{mg} / l$ with considerable fluctuation. During subsequent variations in HRTs from $0.6 \mathrm{hr}$ to $1.0 \mathrm{hr}$ (between days 30 and 120), effluent TOC averaged $30(\mathrm{SD}=22) \mathrm{mg} / \mathrm{l}$. Following day 130, with the HRT at $1.25 \mathrm{hr}$, influent $\mathrm{C}: \mathrm{N}$ was gradually reduced from 2.3 to 1.0. Concurrently, in the same time frame, effluent TOC dropped to a level of $1.9(\mathrm{SD}=0.9) \mathrm{mg} / l$. Under this $\mathrm{C}: \mathrm{N}$ state, HRT was increased from $1.25 \mathrm{hr}$ to $5.0 \mathrm{hr}$ and system performance (TOC and nitrate removal efficiencies and reactor $\mathrm{C}: \mathrm{N}$ ) experienced no significant change. This same steady-state performance pattern was also observed with HRTs of $4.0 \mathrm{hr}$ and $1.25 \mathrm{hr}$ when influent $\mathrm{C}: \mathrm{N}$ was in excess of 1.9 (days 10 to 30 ). Effluent $\mathrm{pH}$ throughout the study was about $7.7(\mathrm{SD}=0.2)$, distinctly higher than the influent value of 6.9 as is expected for a denitrification system.

Sludge Yield Sludge yield was calculated to be $0.235 \mathrm{~g}$-VSS produced/g-TOC removed at a HRT of $1.25 \mathrm{hr}$ and $\mathrm{C}: \mathrm{N}$ of 2.0 corresonpding to an average effulent VSS of $9.1 \mathrm{mg} / l$. Previous work (in-house, not reported) demonstrated a cell yield of 0.7 to $0.8 \mathrm{~g}$-cells/ g-ethanol consumed or about $1.3 \mathrm{~g}$-cells/ $\mathrm{g}$-TOC which is about 5 times higher than the results determined here. In that work yeast were cultivated for single cell protein production without the use of a biomass retention matrix as in this research. A sludge yield of $0.08 \mathrm{~g}$-cells/ $\mathrm{g}$-TOC reported for methane fermentation with a granular sludge, ${ }^{6)}$ however, is slightly lower than results obtained here.

\section{DISCUSSION}

\section{Effects of HRT on System Performance} Nitrogen removal efficiencies as a function of HRT are shown in Figure 3. With influent $\mathrm{C}: \mathrm{N}$ at 1.9 or greater (days 10 to 130 , Figure 2), essentially complete nitrogen removal was achieved at HRT values of $1.25 \mathrm{hr}$ or greater (VLRs of $0.38 \mathrm{~g}-\mathrm{N} / l / \mathrm{d}$ or lower) with progressively reduced removal efficiencies at lower HRTs (higher nitrogenous VLRs). These results fall considerably below a VLR of $1.18 \mathrm{~g}-\mathrm{N} / \mathrm{l} / \mathrm{d}$ demonstrated by Ryu et al. ${ }^{7)}$ for comparable treatment efficiency using a PVA immobilized denitrifying sludge in a fluidized bed process. Furthermore, using a granular sludge in an upflow sludge blanket reactor, Rouse et al. ${ }^{8)}$ achieved complete nitrate removal at a VLR of $0.98 \mathrm{~g}-\mathrm{N} / \mathrm{l} / \mathrm{d}$. It would appear that the lower quantity of biomass carrier used in this work would indeed limit substrate application to a lower range.

Effects of $\mathbf{C}: \mathbf{N}$ on System Performance The stoichiometric equation for complete denitrification (dissimilative) using ethanol as the electron donor is as follows:

$$
\begin{aligned}
& 5 \mathrm{C}_{2} \mathrm{H}_{5} \mathrm{OH}+12 \mathrm{NO}_{3}{ }^{-} \\
& \longrightarrow \quad 6 \mathrm{~N}_{2}+10 \mathrm{CO}_{2}+9 \mathrm{H}_{2} \mathrm{O}+12 \mathrm{OH}^{-}
\end{aligned}
$$

The amount of ethanol required for denitrification of $1.0 \mathrm{mg}$ of $\mathrm{NO}_{3}-\mathrm{N}$ is calculated to be $1.4 \mathrm{mg}$ from Equation 1 . When assimilatory carbon demand is also considered, this ethanol requirement would be increased to approximately $1.7 \mathrm{mg}$ with a corresponding $\mathrm{C}: \mathrm{N}$ of $0.86 . .^{9)}$ However, 


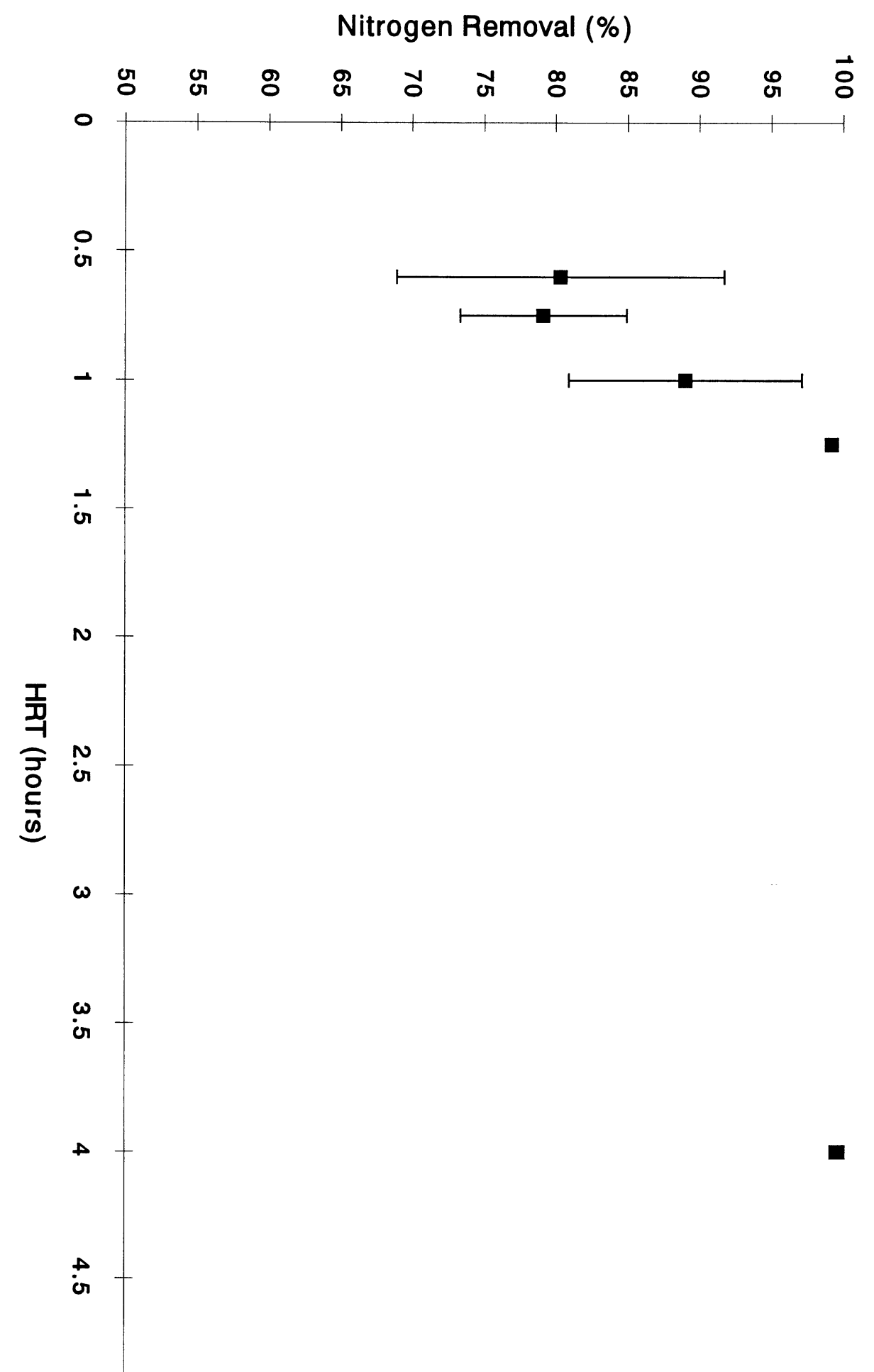

Fig. 3 Effect of hydraulic retention time (HRT) on nitrogen removal efficiency (C: $N \geq$ 1.9). Error bars designate range of \pm 1.0 standard deviation (SD). At HRT of $1.25 \mathrm{hr}$ and $4.0 \mathrm{hr}, 1.0 \mathrm{SD} \leq 0.5 \%$. 
generally 1.5 to 2.0 times this demand is required due to competitive reduction of dissolved oxygen "contamination." Accordingly, to supply a non-limiting carbon source, a $\mathrm{C}: \mathrm{N}$ of 1.9 or greater was used for the initial HRT variation assays (through day 130). Subsequently, at a constant HRT of $1.25 \mathrm{hr}$, influent $\mathrm{C}: \mathrm{N}$ was systematically varied in order to evaluate the effect of this parameter on denitrification efficiency. The results of this study (corresponding to days 130 to 185, Figure 2) are summarized in Figure 4. As shown, with an influent $\mathrm{C}: \mathrm{N}$ of 1.9 or greater, nearly $100 \%$ nitrogen removal efficiency was achieved. Lower $\mathrm{C}: \mathrm{N}$ values progressively resulted in lower nitrogen removals with an efficiency of only $65 \%$ at a $\mathrm{C}: \mathrm{N}$ of 1.0 .

TOC removals, however, demonstrated a reverse relationship with $\mathrm{C}: \mathrm{N}$ loading (Figure 4) approaching a removal efficiency of about $94 \%$ at a $\mathrm{C}: \mathrm{N}$ of 1.0. The inferior TOC removal (75 \%) at higher $\mathrm{C}: \mathrm{N}$ values is possibly due to sulfate reducing conditions initiated with the elimination of nitrate. This is supported by the low ORP (ca. $-150 \mathrm{mv}$ ) observed under these conditions and the disappearance of about $20 \mathrm{mg} / l$ of applied $\mathrm{SO}_{4}{ }^{2-}$ across the reactor.

Complete denitrification is not required for the remediation of groundwater intended for use as a potable water source or otherwise. Furthermore, conditions suitable for complete nitrate removal may not be the most favorable. Considering that lower effluent TOC and VSS were obtained with lower influent $\mathrm{C}: \mathrm{N}$, the results of this study would indicate that a $\mathrm{C}: \mathrm{N}$ of 1.0 (with a HRT of 1.25 or greater) is most efficient (for a potable water supply). Under these conditions, nitrate was reduced to below $10 \mathrm{mg} / l$ as nitrogen and the need for further treatment (removal of TOC, suspended solids, etc.) was minimized.
The acutal organic carbon demand for competative reduction of dissolved oxygen would vary based on system design and operation (exposure to air, deoxygenation, etc.). The optimal $\mathrm{C}: \mathrm{N}$ of 1.0 reported here, therefore, cannont serve as a universal design parameter. It does demonstrate, though, that the most efficient operation may be achieved at a $\mathrm{C}: \mathrm{N}$ considerably below that needed for complete denitrification.

SEM evaluation and assessment of Sponge Carriers Virgin sponge carriers were a cream color which turned brown on the exterior with growth of attached heterotrophic denitrifiers. The interiors of developed sponge cubes were greenish in color. Figure 5-A shows the porous structure of virgin material. Figure 5-B shows surface growth of predominately long rod bacteria. Less dense bacterial growths were evidenced in cube interiors as shown in Figure 5-C. The sponge carriers demonstrated favorable potential for development and retention of biomass while maintaining good fluidization and abrasion resistance characteristics.

\section{CONCLUSION}

A sponge matrix was successfully used for retention of biomass in a denitrification unit process. The following points can be drawn from this study:

(i) At a HRT of 1.25 hours, a C:N of 1.9 or greater was required for near complete removal of influent nitrate in the FBR system investigated in this work.

(ii) Organic carbon removal efficiences were higher at lower $\mathrm{C}: \mathrm{N}$ values (e.g., $95 \%$ TOC removal at a $\mathrm{C}: \mathrm{N}$ of 1.0 ).

(iii) For treatment of a potable water source, operation at a $\mathrm{C}: \mathrm{N}$ below that required for complete nitrogen removal is beneficial (i.e., lower effluent TOC and VSS). 


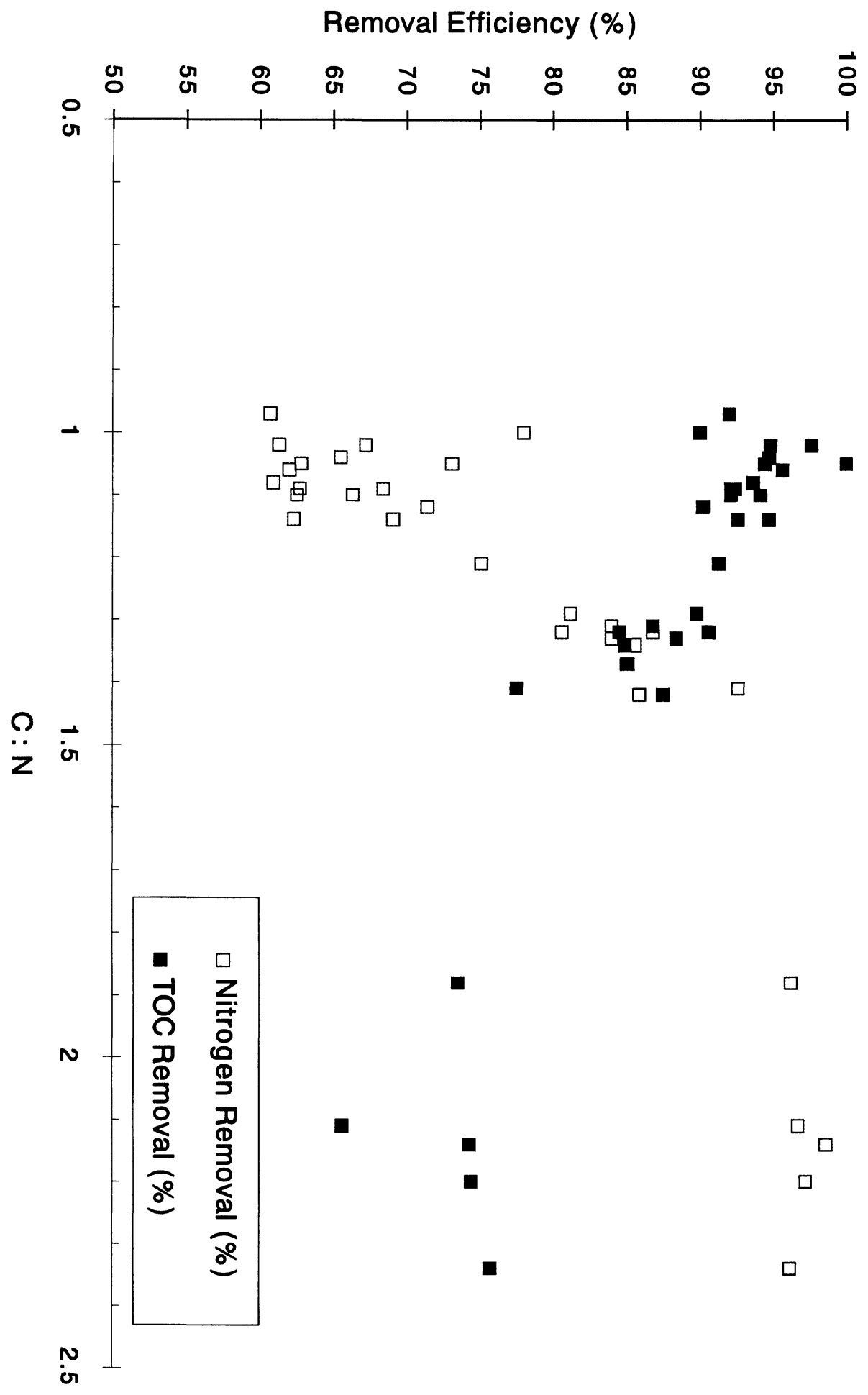

Fig. 4 Effect of carbon to nitrogen ratio $(C: N)$ on nitrogen and TOC removal efficiencies (HRT $=1.25 \mathrm{hr}$ ). 

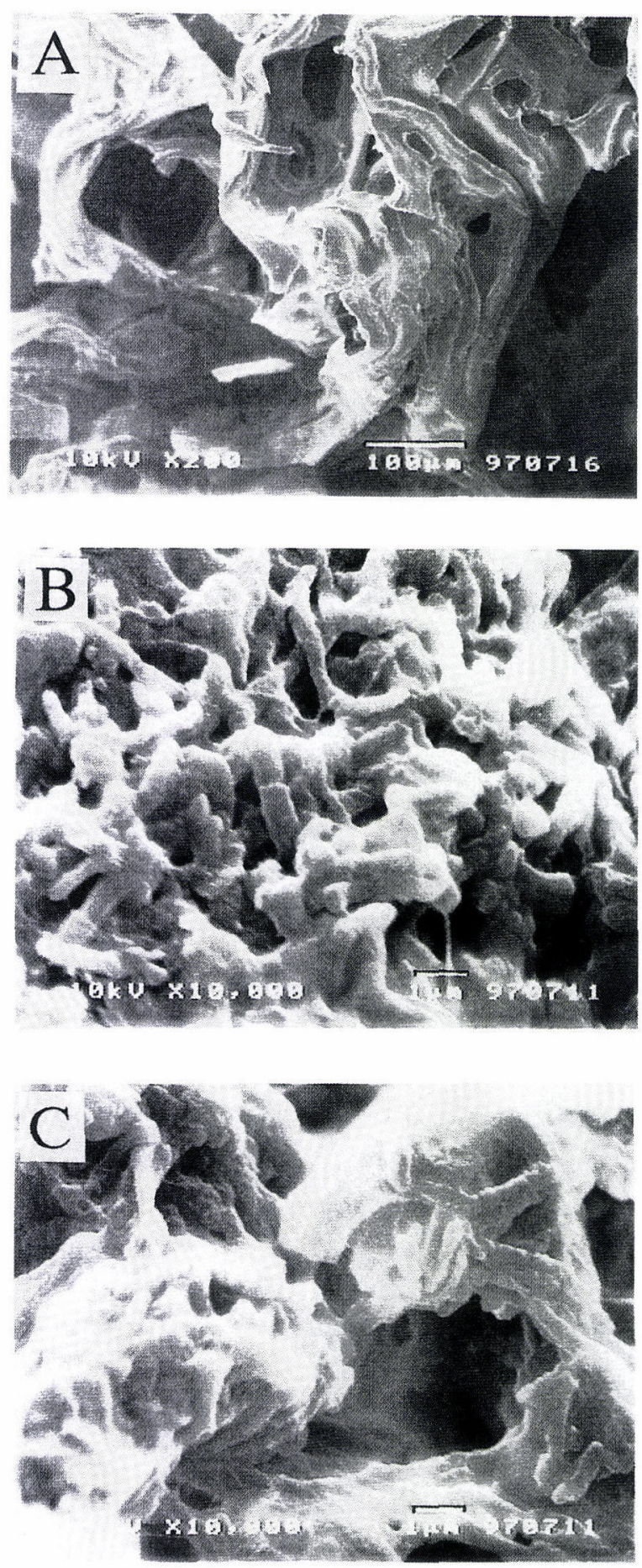

Fig. 5 SEM photographs of sponge biocarrier and attached microorganisms. A) Virgin sponge material, biocarrier (bar $=100 \mu \mathrm{m}$ ); B) Used biocarrier surface with microorganisms (bar $=1 \mu \mathrm{m}) ; C$ ) Interior of used biocarrier (bar $=1 \mu \mathrm{m}$ ). 


\section{ACKNOWLEDGMENTS}

This work was sponsored by a Grant-in-Aid for Scientific Research from the Tree Planting Promoting Organization. Technical assistance of Mr. J. Kijima and Mr. S. Kuroki is gratefully acknowledged.

\section{REFERENCES}

1) Environmental Agency: Environmental White Paper, No. 409, Environ. Agency, Japan (1996).

2 ) Canter L. W.: Nitrates in Groundwater, Lewis Publishers, CRC Press Inc., Boca Raton, FL (1997).

3 ) US EPA: Nitrogen Control Manual, EPA/625/R-93/010. US Environmental Protection Agency, Sept. (1993).

4 ) Tarre S. and Green M.: Precipitation potential as major factor in the formation of granular sludge in an upflow sludge-blanket reactor for denitrification of drinking water, Appl. Microbiol. Biotechnol., 42, 482-486 (1994).

5 ) Green M., Tarre S., Schnizer M., Bogdan B., Armon R. and Shelef G.: Groundwater denitrification using an upflow sludge blanket reactor, Wat. Res., 28, 631-637 (1994).

6 ) Kida K., Morimura S., Sonoda Y., Obe M. and Tanemura K. : Treatment of distillery wastewater from shochu making by an anaerobic fluidized-bed reactor (in Japanese), J. Brew. Soc. Japan, 85, 651-656 (1990).

7 ) Ryu S.-M., Furukawa K. and Fujita M.: Denitrification Treatment of $\mathrm{NO}_{3}-\mathrm{N}$ Polluted Sea Water by Immobilized Acclimated Marine Denitrifying Sludge, Japan. J. Water Treat. Biol. 30, No. 2, 113-120 (1994).

8 ) Rouse J.D., Sumida K. and Furukawa K.: Optimization of granulation by induced precipitation in a soft water for a denitrifying upflow sludge-blanket reactor, Japan Water Treatment Biology Conference, No. 34, Hiroshima, November 1997.

9 ) Hamon M. and Fustec E.: Laboratory and field study of an in situ groundwater denitrification reactor, Res. J. WPCF, 63, 942-949 (1991).

(Submitted 1998. 3. 2) (Accepted 1998. 5. 25) 